\title{
FUNDED PENSIONS - A REMEDY FOR AN AGEING SOCIETY?
}

\author{
MARIUSZ D YBAE *
}

\section{INTRODUCTION}

Private, or more generally, funded ${ }^{1}$ pensions play an important role in the retirement income systems of many OECD countries. This role is expected to grow as recent pension reforms in many OECD countries will lead to a reduction in pay-as-you-go $(\mathrm{PAYG})^{2}$ public pension benefits. ${ }^{3}$ One may ask of why this is so? The aim of this paper is to answer this question.

\section{AgEING Society}

Over the coming decades, the EU, the OECD and many countries will face a significant acceleration of demographic ageing due to three main factors:

- the baby-boom generation reaching retirement age,

- continuing increases in life expectancy,

- decreased fertility since the 1970 s.

It is said that the first of these factors will create a temporary demographic imbalance, while the effects of the two other factors are continuous. $^{4}$

DOI: $10.2478 /$ wrlae-2013-0013

* PhD, LLM; Assistant Professor; University of Wroclaw, Institute of Economic Sciences; mariusz_dybal@prawo.uni.wroc.pl

1 In a funded plan, contributions from the employer, and sometimes also from plan members, are invested in a fund towards meeting the benefits. The future returns on the investments, and the future benefits to be paid, are not known in advance, so there is no guarantee that a given level of contributions will be sufficient to meet the benefits.

${ }^{2}$ In an unfunded defined benefit pension, no assets are set aside and the benefits are paid for by the employer or other pension sponsor as and when they are paid out. Pension arrangements provided by the state in most countries in the world are unfunded, with benefits paid directly from current workers' contributions and taxes. This method of financing is known as Pay-as-you-go (PAYGO or PAYG). The social security systems of many European countries are unfunded, having benefits paid directly out of current taxes and social security contributions, although several countries have hybrid systems which are partially funded.

3 'OECD Pensions Outlook 2012' (OECD 2012) 100.

4 'Adequate and sustainable pensions. Joint report by the Commission and the Council' (European Commission 2003) 12. 
In the early part of the 20th century, most of the gains in total life expectancy were due to greater mortality at younger ages: at birth, during childhood and at working age. But in the second half of the 20th century, mortality risk at retirement ages has also fallen significantly. Between 1960 and 2010, OECD-average life expectancy at age 65 increased by around 3.9 years for men and 5.4 years for women (Figure 1). Increases in life expectancy at age 60 were larger than at age 65. The United Nations population division projects further increases in life expectancy between 2010 and 2050. These amount to 3.1 additional years for men and 3.6 years for women at age 65 . As in the past, the lengthening of life expectancy at age 60 is greater, but by a smaller margin than observed between 1960 and $2010 .^{5}$

Figure 1. Life expectancy at age 60 and 65 by sex, OECD average, 1960-2050

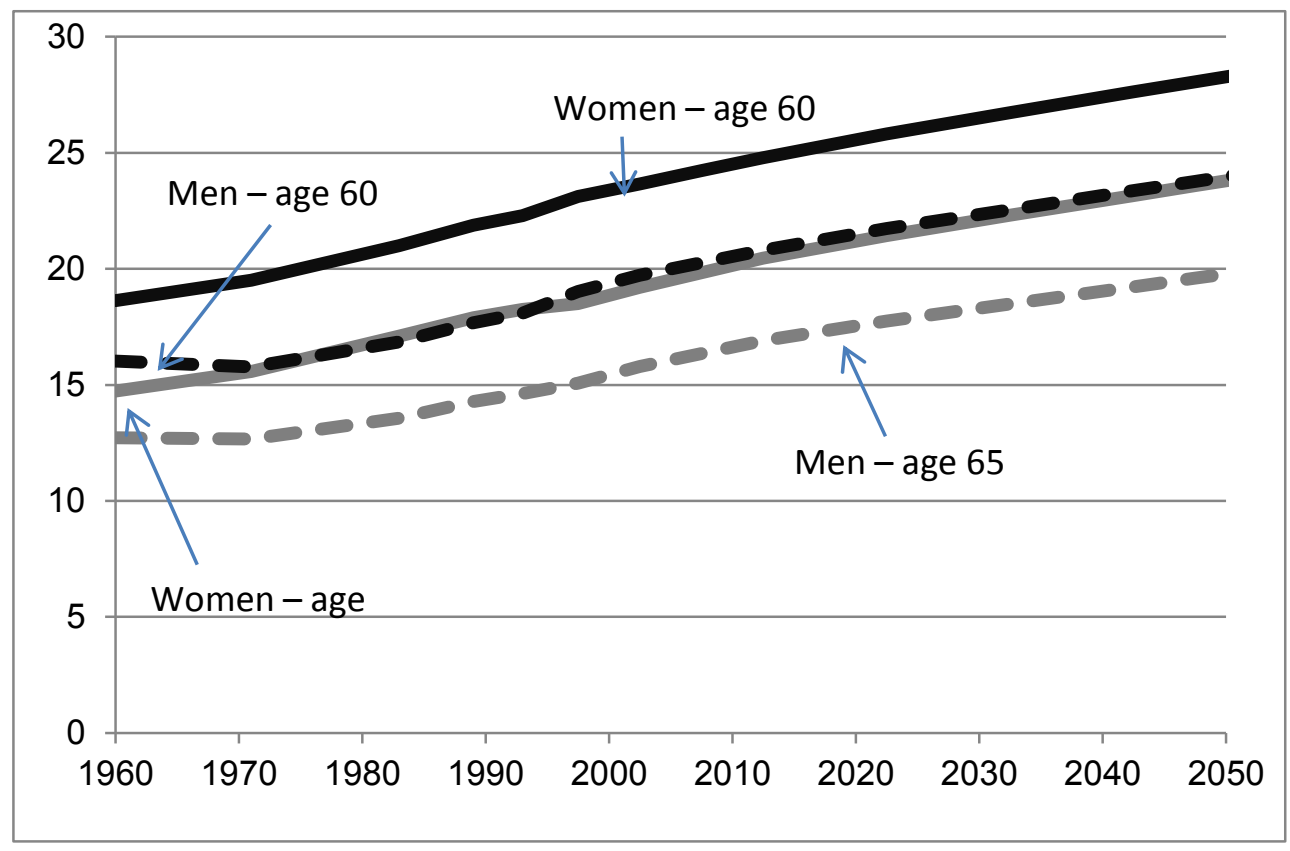

Source: Historical data on life expectancy from the OECD Health database 1960-95. Recent data and projections of life expectancy in the future based on the United Nations Population Division database, World Population Prospects - The 2008 Revision.

The Total Fertility Rate (TFR) in a particular year may be defined as the number of children that would be born to each woman if she were to live to the end of her childbearing years and if the likelihood of her giving birth to children at each age was equal to the currently prevailing age-specific fertility rates. It is generally computed by summing up the age-specific fertility rates defined over a five-year interval. Assuming there are no migration flows and that mortality rates remain unchanged, a total fertility rate of 2.1 children per woman generates broad population stability; this is also referred to as the 'replacement fertility rate', as it ensures replacement of the woman and her partner with another 0.1 percentage points to counteract infant mortality (CO1.1). The Completed Fertility Rate (CFR)

5 'Pensions at a glance 2011: Retirement-income systems in OECD and G20 countries' (OECD 2011) 27. 
presents the number of children actually born per woman for a given cohort of women by the end of their childbearing years. Usually, women who are 45 (in some countries 49) or older are considered to have completed their childbearing years. ${ }^{6}$

\section{Table 1. Total fertility rates}

\begin{tabular}{|c|c|c|c|c|c|}
\hline Country $\backslash$ Year & 1990 & 1995 & 2000 & 2005 & 2010 \\
\hline Belgium & 1.62 & 1.56 & 1.67 & 1.76 & : \\
\hline Bulgaria & 1.82 & 1.23 & 1.26 & 1.32 & 1.49 \\
\hline Czech Republic & 1.9 & 1.28 & 1.14 & 1.28 & 1.49 \\
\hline Denmark & 1.67 & 1.8 & 1.77 & 1.8 & 1.87 \\
\hline Germany & $:$ & $:$ & 1.38 & 1.34 & 1.39 \\
\hline Estonia & 2.05 & 1.38 & 1.38 & 1.5 & 1.63 \\
\hline Ireland & 2.11 & 1.84 & 1.89 & 1.86 & 2.07 \\
\hline Greece & 1.4 & 1.31 & 1.26 & 1.33 & 1.51 \\
\hline Spain & 1.36 & 1.17 & 1.23 & 1.34 & 1.38 \\
\hline France & $:$ & : & 1.89 & 1.94 & 2.03 \\
\hline Italy & 1.33 & 1.19 & 1.26 & 1.32 & 1.41 \\
\hline Cyprus & 2.41 & 2.03 & 1.64 & 1.42 & 1.44 \\
\hline Latvia & $:$ & $:$ & : & 1.31 & 1.17 \\
\hline Lithuania & 2.03 & 1.55 & 1.39 & 1.27 & 1.55 \\
\hline Luxembourg & 1.6 & 1.7 & 1.76 & 1.63 & 1.63 \\
\hline Hungary & 1.87 & 1.57 & 1.32 & 1.31 & 1.25 \\
\hline Malta & 2.04 & 1.81 & 1.7 & 1.38 & 1.38 \\
\hline Netherlands & 1.62 & 1.53 & 1.72 & 1.71 & 1.79 \\
\hline Austria & 1.46 & 1.42 & 1.36 & 1.41 & 1.44 \\
\hline Poland & 2.06 & 1.62 & 1.37 & 1.24 & 1.38 \\
\hline Portugal & 1.56 & 1.41 & 1.55 & 1.4 & 1.36 \\
\hline Romania & 1.83 & 1.33 & 1.31 & 1.32 & 1.33 \\
\hline Slovenia & 1.46 & 1.29 & 1.26 & 1.26 & 1.57 \\
\hline Slovakia & 2.09 & 1.52 & 1.3 & 1.25 & 1.4 \\
\hline Finland & 1.78 & 1.81 & 1.73 & 1.8 & 1.87 \\
\hline Sweden & 2.13 & 1.73 & 1.54 & 1.77 & 1.98 \\
\hline United Kingdom & 1.83 & 1.71 & 1.64 & 1.78 & 1.98 \\
\hline Iceland & 2.3 & 2.08 & 2.08 & 2.05 & 2.2 \\
\hline Norway & 1.93 & 1.87 & 1.85 & 1.84 & 1.95 \\
\hline Switzerland & 1.58 & 1.48 & 1.5 & 1.42 & 1.52 \\
\hline Albania & $:$ & $:$ & $:$ & 1.61 & : \\
\hline Croatia & $:$ & $:$ & $:$ & 1.41 & 1.46 \\
\hline Montenegro & $:$ & $:$ & $:$ & 1.6 & 1.69 \\
\hline $\begin{array}{l}\text { Former Yugoslav Republic of } \\
\text { Macedonia }\end{array}$ & $:$ & 2.13 & 1.88 & 1.46 & 1.56 \\
\hline Serbia & $:$ & : & 1.48 & 1.45 & 1.4 \\
\hline Turkey & $:$ & $:$ & : & : & 2.04 \\
\hline
\end{tabular}

Source: Eurostat

$<$ http://epp.eurostat.ec.europa.eu/tgm/table.do?tab=table\&init=1\&plugin=1\&language=en \& pcode $=$ tsdde $220>$ accessed 18 November 2012 . 
Table 1. shows that in 2010 TFRs were well below the replacement rate in most countries, but exceed two children per woman in Iceland, Ireland, Turkey and France. Among them only Iceland (2.2) was able to exceed the replacement rate. In contrast, the lowest Total Fertility Rate was observed in Latvia (1.17) followed by Hungary (1.25) and Romania (1.33). Twenty years earlier the highest Total Fertility Rate was in Cyprus (2.41) followed by Iceland (2.3), Sweden (2.13) and Ireland (2.11). Only these four countries were able to exceed the replacement rate. Additionally, five countries achieved TFR higher than two (Estonia, Lithuania, Malta, Poland and Slovakia). In 1990, the lowest TFR value was observed in Italy (1.33) followed by Spain (1.36) and Greece (1.4). To sum up, in the years 19901995-2000-2005-2010 we cannot find a single country with an increasing Total Fertility Rate.

Eventually, all three factors mentioned (the baby-boom generation reaching retirement age, continuing increases in life expectancy, decreased fertility since the 1970s) will combine to produce a major financial challenge for pensions systems over the coming decades when the number of pensioners will rapidly increase and the size of the working age population will diminish.

Table 2. Projections of Old-Age Dependency in EU and EUA Countries, 2000-2050 (ratio of people aged over 64 to working age population, percent)

\begin{tabular}{|c|c|c|c|c|c|c|}
\hline Country/Year & 2000 & 2010 & 2020 & 2030 & 2040 & 2050 \\
\hline Austria & 25 & 29 & 32 & 44 & 55 & 55 \\
\hline Belgium & 28 & 29 & 36 & 46 & 51 & 50 \\
\hline Denmark & 24 & 27 & 34 & 39 & 45 & 42 \\
\hline Finland & 25 & 28 & 39 & 47 & 47 & 48 \\
\hline France & 27 & 28 & 36 & 44 & 50 & 51 \\
\hline Germany & 26 & 33 & 36 & 47 & 55 & 53 \\
\hline Greece & 28 & 32 & 36 & 42 & 51 & 59 \\
\hline Ireland & 19 & 19 & 25 & 30 & 36 & 44 \\
\hline Italy & 29 & 34 & 40 & 49 & 64 & 67 \\
\hline Luxembourg & 23 & 26 & 31 & 40 & 45 & 42 \\
\hline Netherlands & 22 & 25 & 33 & 42 & 48 & 45 \\
\hline Portugal & 25 & 27 & 30 & 35 & 43 & 49 \\
\hline Spain & 27 & 29 & 33 & 42 & 56 & 66 \\
\hline Sweden & 30 & 31 & 38 & 43 & 47 & 46 \\
\hline United Kingdom & 26 & 27 & 32 & 40 & 47 & 46 \\
\hline EU15 average & 27 & 30 & 35 & 44 & 52 & 53 \\
\hline Bulgaria & 24 & 24 & 29 & 34 & 41 & 53 \\
\hline Cyprus & 18 & 20 & 26 & 32 & 34 & 39 \\
\hline Czech Republic & 20 & 22 & 32 & 38 & 47 & 59 \\
\hline Estonia & 23 & 25 & 30 & 36 & 42 & 57 \\
\hline Hungary & 21 & 23 & 29 & 33 & 40 & 50 \\
\hline Latvia & 23 & 26 & 29 & 37 & 44 & 56 \\
\hline Lithuania & 21 & 24 & 26 & 35 & 40 & 43 \\
\hline Malta & 18 & 22 & 32 & 39 & 40 & 46 \\
\hline Poland & 18 & 18 & 26 & 33 & 37 & 50 \\
\hline Romania & 20 & 20 & 24 & 26 & 36 & 45 \\
\hline Slovak Republic & 16 & 17 & 23 & 30 & 36 & 47 \\
\hline Slovenia & 20 & 24 & 32 & 44 & 53 & 64 \\
\hline EUA average & 20 & 22 & 28 & 35 & 41 & 51 \\
\hline
\end{tabular}

Source: EU countries - 'Budgetary challenges posed by ageing populations: The impact of public spending on pensions, health and long-term care for the elderly and possible 
indicators of long-term financial sustainability of public finances' (European Union 2001) 12; EUA countries - 'World Population Prospects: The 2002 Revision' (United Nations 2002) 65 .

As a result, the old-age dependency ratio for the EU15 is projected to nearly double from $27 \%$ in 2000 to $53 \%$ by 2050 (Table 2), based on rather optimistic assumptions about total fertility rates (assumed to rise again to 1.8 children per women in most countries) and life expectancy (assumed to rise less than in the past). ${ }^{7}$ The projection for the EU accession countries (EUA) goes even further (Table 2). The old-age dependency ratio for these countries is projected to increase from $20 \%$ in 2000 to $51 \%$ by 2050 . In 2000 , the lowest old-age dependency ratios can be found in Ireland (19\%), and the Slovak Republic (16\%) for EU and EUA countries respectively. In contrast, the highest ratios were observed in Sweden (30\%), and Bulgaria (24\%) for EU and EUA countries respectively. According to the projections, in 2050 the lowest the old-age dependency ratio among EU countries should be found in Luxembourg and Denmark (both 42\%). In projections for EUA countries the lowest ratio is in Cyprus (39\%). On the other hand, the highest ratios are projected in Italy $(67 \%)$, and Slovenia (64\%) for EU and EUA countries respectively. Taking into account the period from 2000-2050, the highest increase of old-age dependency ratios can be found in Spain (39\%), and Slovenia (44\%) for EU and EUA countries respectively.

Based on these projected changes in old-age dependency ratios in the East and the West, and in a no-reform scenario, expenditures would roughly increase. ${ }^{8}$ Confirmation of this process can be seen in the forthcoming table.

According to Table 3, Italy has spent the largest proportion of national income on pensions among OECD countries since 2007: 14.1\% (nearly one-seventh) of GDP. Other countries with high public pension spending are also found in continental Europe, with Austria, France and Greece at about $12 \%$ of GDP and Germany, Poland and Portugal at about $11 \%$. Pensions generally account for between $25 \%$ and $30 \%$ of total public expenditure in these countries. High spending partly results from demographics: these seven countries are among the oldest of OECD countries. The left-hand chart compares pension spending in 2007 with the old-age dependency ratio for that year. There is a strong relationship, but it is far from deterministic. Countries such as Japan, Sweden, Switzerland and the United Kingdom face similar or worse demographics but have significantly lower pension spending than the seven countries at the top of the scale. Iceland, Korea and Mexico spend less than 2\% of GDP on public pensions. They are all relatively young countries. Also, Korea's pension system is immature: the public, earnings-related scheme was only established in 1998. In Mexico, low spending also reflects the relatively

\footnotetext{
${ }^{7}$ Robert Holzmann, Landis MacKellar, and Michal Rutkowski, 'Accelerating the European Pension reform agenda: need, progress, and conceptual underpinnings' in Robert Holzmann, Mitchell Orenstein, Michal Rutkowski (eds.) Pension reform in Europe: Process and Progress (The World Bank 2003) 4.

${ }^{8}$ Robert Holzmann and Edward Palmer, Pension Reform. Issues and Prospects for NonFinancial Defined Contribution (NDC) Schemes (The World Bank 2006) 227.
} 
narrow coverage of pensions (only around 35\% of employees). In Iceland, much of retirement income is provided by compulsory occupational schemes, leaving less of a role for the public sector in providing old-age income. Spending also tends to be low in other countries with favourable demographics, such as Australia, Canada, Ireland and New Zealand. However, this is not always the case: Turkey spends $6 \%$ of GDP on public pensions despite being the second-youngest OECD country in demographic terms. This is more than Denmark, the Netherlands, the United Kingdom and the United States, despite the fact that these countries have 2-3 times as many over- 65 s relative to population as Turkey does. ${ }^{9}$

Pension spending was a fairly stable proportion of GDP over the period 1990-2007 in six countries: Belgium, Canada, Ireland, Spain, Sweden and the United States. In five countries, public pension spending grew more slowly than national income. In New Zealand, the decline of over $40 \%$ reflects two policies: freezing the value of the basic pension in 1992-94 and increasing the pension age from 60 to 65 . There were significant falls in pension spending in Iceland, Luxembourg, the Netherlands and Norway as well. Public pension expenditure more than doubled relative to national income in six OECD countries. In Korea, Mexico and (to a lesser degree) Turkey, this reflected the low starting point in 1990. However, Poland and Portugal moved from spending below the OECD average to well above it. The change in Japan results from rapid demographic ageing. ${ }^{10}$

Table 3. Public expenditure on old-age and survivors benefits

\begin{tabular}{|c|c|c|c|c|c|c|c|c|}
\hline & \multicolumn{5}{|c|}{ Level (\% of GDP) } & \multirow{2}{*}{$\begin{array}{c}\begin{array}{c}\text { Change } \\
(\%)\end{array} \\
1990- \\
2007 \\
\end{array}$} & \multicolumn{2}{|c|}{$\begin{array}{l}\text { Level (\% of } \\
\text { total } \\
\text { government } \\
\text { spending) }\end{array}$} \\
\hline & 1990 & 1995 & 2000 & 2005 & 2007 & & 1990 & 2007 \\
\hline Australia & 3.0 & 3.6 & 3.8 & 3.3 & 3.4 & 11.2 & 8.6 & 10.1 \\
\hline Austria & 11.4 & 12.3 & 12.3 & 12.5 & 12.3 & 7.8 & 22.1 & 25.3 \\
\hline Belgium & 9.1 & 9.4 & 8.9 & 9.0 & 8.9 & -2.9 & 17.4 & 18.3 \\
\hline Canada & 4.2 & 4.7 & 4.3 & 4.2 & 4.2 & -1.2 & 8.5 & 10.6 \\
\hline Chile & & 6.9 & 7.5 & 5.9 & 5.2 & & & \\
\hline $\begin{array}{l}\text { Czech } \\
\text { Republic }\end{array}$ & 6.1 & 6.3 & 7.5 & 7.3 & 7.4 & 21.8 & & 17.5 \\
\hline Denmark & 5.1 & 6.2 & 5.3 & 5.4 & 5.6 & 8.6 & 9.2 & 10.9 \\
\hline Estonia & & & 6.0 & 5.3 & 5.2 & & & 15.2 \\
\hline Finland & 7.3 & 8.8 & 7.7 & 8.4 & 8.3 & 13.3 & 15.1 & 17.5 \\
\hline France & 10.6 & 12.0 & 11.8 & 12.3 & 12.5 & 17.5 & 21.5 & 23.9 \\
\hline Germany & 9.0 & 10.7 & 11.2 & 11.5 & 10.7 & 19.1 & & 24.5 \\
\hline
\end{tabular}

9 'Pensions at a Glance 2011: Retirement-income Systems in OECD and G20 Countries' (OECD 2011) 154.

$10<\mathrm{http}$ //www.oecd-ilibrary.org/pensions-at-a-glance2011_5km4sjtc8vzw.pdf;jsessionid=1132th7u46gi2.x-oecd-live-

01 ? contentType $=/ \mathrm{ns} /$ StatisticalPublication, $/ \mathrm{ns} /$ Book\&itemId $=/$ content/book/pension_glance -2011-

en\&containerItemId=/content/serial/19991363\&accessItemIds=\&mimeType=application $/ \mathrm{p}$ df $>$

accessed 18 November 2012. 


\begin{tabular}{|l|r|r|r|r|r|r|r|r|}
\hline Greece & 9.9 & 9.6 & 10.7 & 11.7 & 11.9 & 20.9 & & 26.3 \\
\hline Hungary & & & 7.4 & 8.6 & 9.1 & & & 18.3 \\
\hline Iceland & 2.2 & 2.4 & 2.2 & 2.0 & 1.9 & -14.7 & & 4.5 \\
\hline Ireland & 3.9 & 3.5 & 3.1 & 3.4 & 3.6 & -7.7 & 9.0 & 9.7 \\
\hline Israel & & 4.7 & 4.9 & 5.1 & 4.8 & & & 10.7 \\
\hline Italy & 10.1 & 11.3 & 13.6 & 14.0 & 14.1 & 38.9 & 19.1 & 29.4 \\
\hline Japan & 4.9 & 6.1 & 7.4 & 8.7 & 8.8 & 80.5 & & 27.0 \\
\hline Korea & 0.7 & 1.2 & 1.4 & 1.5 & 1.7 & 130.5 & 3.7 & 5.7 \\
\hline Luxembourg & 8.2 & 8.8 & 7.5 & 7.2 & 6.5 & -19.8 & 21.6 & 18.1 \\
\hline Mexico & 0.5 & 0.7 & 0.9 & 1.2 & 1.4 & 202.0 & & 7.2 \\
\hline Netherlands & 6.7 & 5.8 & 5.0 & 5.0 & 4.7 & -29.8 & 12.2 & 10.4 \\
\hline New Zealand & 7.4 & 5.7 & 5.0 & 4.3 & 4.3 & -41.8 & 14.0 & 10.9 \\
\hline Norway & 5.6 & 5.5 & 4.8 & 4.8 & 4.7 & -16.6 & & 11.4 \\
\hline Poland & 5.1 & 9.4 & 10.5 & 11.4 & 10.6 & 107.0 & & 25.2 \\
\hline Portugal & 4.9 & 7.2 & 7.9 & 10.3 & 10.8 & 119.8 & & \\
\hline Slovak & & & & & & & & \\
Republic & & 6.3 & 6.3 & 6.2 & 5.8 & & & 17.0 \\
\hline Slovenia & & & 10.6 & 9.9 & 9.6 & & & 22.7 \\
\hline Spain & 7.9 & 9.0 & 8.6 & 8.1 & 8.0 & 1.5 & & 20.5 \\
\hline Sweden & 7.7 & 8.2 & 7.2 & 7.6 & 7.2 & -6.8 & & 14.1 \\
\hline Switzerland & 5.6 & 6.7 & 6.6 & 6.8 & 6.4 & 14.2 & 18.6 & 19.9 \\
\hline Turkey & 2.4 & 2.7 & 4.9 & 5.9 & 6.1 & 159.2 & & \\
\hline United & & & & & & & & \\
Kingdom & 4.8 & 5.4 & 5.3 & 5.6 & 5.4 & 11.0 & 11.6 & 12.0 \\
\hline United States & 6.1 & 6.3 & 5.9 & 5.9 & 6.0 & -1.5 & 16.4 & 16.3 \\
\hline OECD34 & $\mathbf{6 . 1}$ & $\mathbf{6 . 7}$ & $\mathbf{6 . 9}$ & $\mathbf{7 . 1}$ & $\mathbf{7 . 0}$ & $\mathbf{1 4 . 5}$ & & $\mathbf{1 6 . 5}$ \\
\hline Sour: OECD Socis & & & & & & \\
\hline
\end{tabular}

Source: OECD Social Expenditures database (SOCX); OECD Main Economic Indicators database. $<$ http://dx.doi.org/10.1787/888932371063> accessed 18 November 2012.

\section{PAY-AS-YOU-GO VS FULLY FUNDED}

As one can see, rapid ageing of the population around the world is a major challenge to affordability of pensions and financial sustainability of retirement income systems. In fact, pension policy has always involved balancing the adequacy of benefits with their affordability. This balancing act has got harder as a result of the recent economic and financial crisis. It adds to the existing and much greater challenge to pension systems arising from population ageing. Despite these short-term problems, it is important to remember that pensions are a long-term issue. In the first instance, there is an obvious trade-off between adequacy and sustainability: higher public pensions deliver larger incomes in old age but cost more. However, if public pensions are at risk of being inadequate, there will be pressure for ad hoc increases in pensions or supplementary retirement benefits to prevent oldage poverty.

Similarly, pension benefits can be too high, rendering the system financially unsustainable. If governments delay reforms, then the scale of adjustment to benefits needed in the medium or long term will be more sudden and painful. Greece, Hungary and Ireland have all had to accept substantial pension reforms as part of the fiscal consolidation required for international bail-outs. Such sudden changes make it very difficult for individuals to change their work, retirement and savings decisions to reflect the new 
financial realities. How can governments maintain retirement income adequacy without endangering financial sustainability? There are two main routes out of this dilemma. ${ }^{11}$ Major reforms and minor (parametric) ones. Minor reforms of pay-as-you-go systems broken down into type of reform, measure of change as well as chosen action are presented in Table 4.

Table 4. Parametric (minor) reforms of traditional (pay-as-you-go) systems

\begin{tabular}{|c|c|c|}
\hline $\begin{array}{l}\text { Type of } \\
\text { reform }\end{array}$ & Measure of change & Action \\
\hline \multirow{2}{*}{$\begin{array}{l}\text { Eligibility } \\
\text { criteria }\end{array}$} & Retirement age & \multirow{2}{*}{$\begin{array}{l}\text { Altering the retirement age or the service years } \\
\text { required to qualify for a pension. }\end{array}$} \\
\hline & Service years & \\
\hline \multirow{5}{*}{$\begin{array}{l}\text { Contribution } \\
\text { structure }\end{array}$} & Coverage & \multirow{5}{*}{$\begin{array}{l}\text { Raising the contribution rates of employers rather } \\
\text { than that of employees and abolishing minimum } \\
\text { income limits or increasing the maximum income } \\
\text { limits on which the contributions are made, to } \\
\text { maximize the total amount of } \\
\text { contributions collected. }\end{array}$} \\
\hline & Contribution rate & \\
\hline & Contribution base & \\
\hline & Source & \\
\hline & $\begin{array}{l}\text { Taxation of } \\
\text { contributors }\end{array}$ & \\
\hline \multirow[b]{6}{*}{$\begin{array}{l}\text { Benefit } \\
\text { structure }\end{array}$} & Benefit formula & \multirow{6}{*}{$\begin{array}{l}\text { Countries with older populations (such as } \\
\text { Portugal and Switzerland) decreased accrual rates } \\
\text { or increased the number of years used to } \\
\text { calculate the pensionable salary (which decreases } \\
\text { it), leading to lower replacement rates. However, } \\
\text { younger countries (such as Senegal and Sudan) } \\
\text { modified their pension formulas (through higher } \\
\text { accrual rates, higher pensionable salary or higher } \\
\text { percent of replacement) such that they increased } \\
\text { their benefits. As to changing the way benefits } \\
\text { are indexed to inflation, the most important } \\
\text { improvements were for those countries that } \\
\text { replaced their ad hoc inflation adjustment with a } \\
\text { structured adjustment, whether they tied these } \\
\text { adjustments to price or wage changes. }\end{array}$} \\
\hline & Pension base & \\
\hline & Indexation & \\
\hline & Minimum pension & \\
\hline & Payment form & \\
\hline & Taxation of benefits & \\
\hline \multirow{2}{*}{$\begin{array}{l}\text { Administratio } \\
\mathrm{n}\end{array}$} & $\begin{array}{l}\text { Ministerial } \\
\text { authority }\end{array}$ & \multirow[t]{2}{*}{ Strengthening the role of public administration. } \\
\hline & Investment policy & \\
\hline
\end{tabular}

Source: AM Schwarz, A Demirguc-Kunt, Taking stock of pension reforms around the world (The World Bank 1999) 19.

Unfortunately, the parametric reforms mentioned offer only limited options. Raised contribution rates have negative effects on the labour market, encourage evasion and are unpopular. Moreover, the cost of the system falls on the younger generations because despite parametric changes, unfunded liabilities have continued to increase in many countries. To cut a long story short, the effect of parametric changes on the financial balance of the system is only temporary.

To deal with it on a permanent basis, countries should replace (totally or partially) public pay-as-you-go systems with private, fullyfunded, individual programs. Why? Because in a private, fully-funded individual program:

11 'Pensions at a Glance 2011: Retirement-income Systems in OECD and G20 Countries' (OECD 2011) 9.

$<$ http://dx.doi.org/10.1787/pension_glance-2011-enx> accessed 18 November 2012. 
- $\quad$ Each member pays a percentage of his/her gross wage into an individual account which is his/her personal property.

- The pension fund administrators (AFP), manage the resources that have been deposited, investing them in financial instruments, which produces a return.

- $\quad$ The AFPs' investment instruments are regulated by law and are duly diversified.

- $\quad$ There is independence between the pension fund and the company managing it.

- $\quad$ The AFPs charge a commission for managing the resources.

- When the member retires, he/she has access to the resources that have been accumulated, plus the interest gained by the yield of the investments, in the form of a pension.

- The member chooses the pension mode: Programmed Withdrawal or Life Annuity. ${ }^{12}$

Moreover, fully-funded pensions have a positive influence on the financial markets. To be more specific, three basic channels of the impact of funded pensions on financial development can be distinguished. Firstly, direct changes in savings and the size and composition of the financial system as a result of a move of mandatory pension contributions from a PAYG to a funded system. Pension reform can affect the savings rate of the economy and hence change the level of financial intermediation. Secondly, direct effects on financial intermediation are also to be expected. If the transition from a PAYG to a funded system takes place through the issuing of public debt, market capitalization will grow and the maturity of public debt could increase. The development of a public debt market could in turn foster the growth of the market for private securities. Thirdly, changes could occur in the efficiency and composition of financial intermediation as a result of the emergence of pension funds and other institutional investors. Some improvements in the operation of the financial system may result from regulatory reform and the operation of pension funds and other institutional investors that would participate in the new funded system. ${ }^{13}$

Table 5 Expansion of the mandatory fully-funded pension

\begin{tabular}{|l|c|}
\hline \multicolumn{1}{|c|}{ Country } & $\begin{array}{c}\text { Year when the mandatory fully-funded } \\
\text { individual system began }\end{array}$ \\
\hline Chile & 1981 \\
\hline Peru & 1993 \\
\hline Colombia & 1994 \\
\hline Uruguay & 1996 \\
\hline Bolivia, Mexico & 1997 \\
\hline El Salvador, Hungary, Kazakhstan & 1998 \\
\hline
\end{tabular}

12 AE Guillermo, 'Ageing and fully-funded pensions' Presentation prepared for the International Symposium on Business Responses to the Demographic Challenge (Geneva, 28th and 29th April 2009).

13 J Yermo, The Role of Funded Pensions in Retirement Income Systems: Issues for the Russian Federation (OECD 2012) 12. 


\begin{tabular}{|l|c|}
\hline Poland & 1999 \\
\hline Costa Rica & 2000 \\
\hline Latvia & 2001 \\
\hline Bulgaria, Estonia, Kosovo, Panama $(*)$ & 2002 \\
\hline Russian Federation, Dominican Republic & 2003 \\
\hline Croatia, Lithuania, India $(*)$ & 2004 \\
\hline Slovakia, Macedonia, Nigeria & 2005 \\
\hline Romanía & 2008 \\
\hline Ukraine $(* *)$ & \\
\hline Armenia $(* *)$ & \\
\hline
\end{tabular}

$\left(^{*}\right)$ Reform for employees in the Public Sector.

(**) Reform passed but not implemented.

$(* * *)$ Reform proposed but not yet passed or implemented.

Source: Mariusz Dybał Efektywność inwestycyjna funduszy emerytalnych (CeDeWu 2008) 35 .

Therefore it is not surprising that more and more countries are choosing the fully-funded pension. Table 5 demonstrates that 25 countries have set up mandatory, fully-funded, individual programs and other countries are in the middle of the legislative process.

All pensions, whether PAYG-financed or funded, are claims on future production. In a theoretical economic sense, therefore, it matters little how pensions are financed, as ultimately it is the current working population that has to produce the goods and services that will be consumed by the retired population. However, the practice is rather different for four main reasons:

- Funded pensions can rely on foreign investment to finance future benefits. To the extent that one can invest in economies growing faster than the one where the pensioner is based, the final pension pot can be increased;

- PAYG pensions can be linked to some extent to the evolution of wages in the economy. To the extent that wages follow inflation, PAYG systems can provide good inflation protection to pensioners;

- Funded pensions rely on the accumulation of assets whose market price at any time may differ from the fundamental value of the underlying capital assets. This market risk is borne by individuals and will cause fluctuations in the level of pension benefits unless there are risk sharing and pooling mechanisms in place. At the same time, market risk, or more generally the volatility of financial asset prices, is associated with risk premium, that is, an excess of returns over assets with little or no risk;

- PAYG pensions rely on an implicit intergenerational contract between the working and the retired population. When demographic or economic conditions change, this contract can break down. Demographic ageing and slow growth create a natural stress on intergenerational contracts. As the size of the elderly population increases, so does its political power, at a time when financing the same level of pensions becomes increasingly difficult. By contrast, with funded pensions, claims consist of securities that have legally enforceable rights to payments from companies or the state. 
From this discussion, it is clear that both PAYG and funded systems have advantages and disadvantages. For precisely this reason, the OECD has often stressed the need for a mixed-financing ${ }^{14}$ pension system that combines PAYG and funding to achieve an adequate level of retirement income. ${ }^{15}$

Figure 2 Taxonomy: different types of retirement-income provision

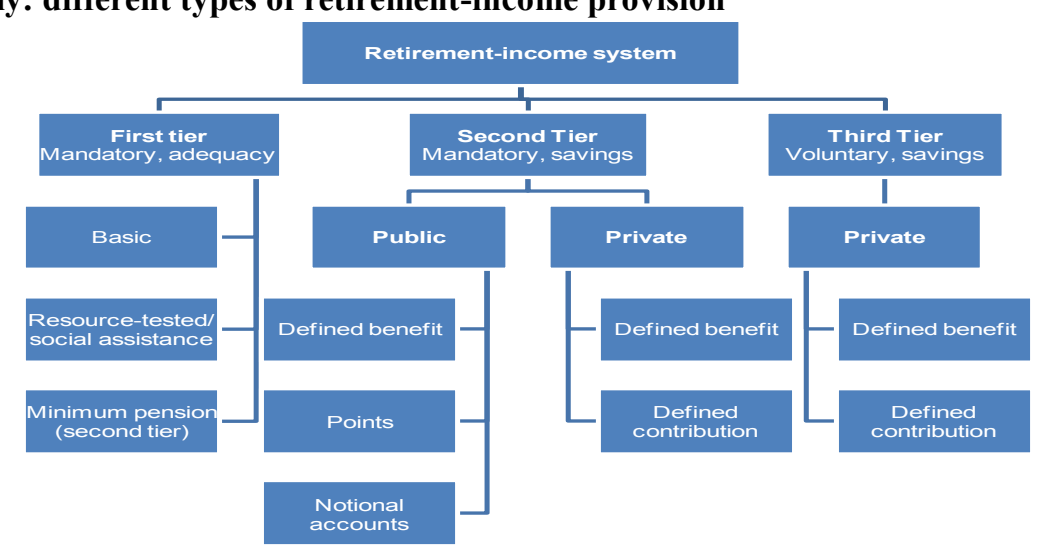

Source: See Chapter 1 of 'Pensions at a Glance: Public Policies across OECD Countries' (OECD 2005) and 'OECD Classification and Glossary of Private Pensions' (OECD 2004) for a more detailed discussion of classification issues.

The framework, shown in Figure 2, presents this mixed-financing pension system. The redistributive first-tier comprises programmes designed to ensure pensioners achieve a minimum standard of living. The second-tier savings components are designed to achieve a target standard of living in retirement compared with the one maintained during the pensioner's working years. Within these tiers (pillars), schemes are classified further by provider (public PAYG or private fully-funded) and the way benefits are determined.

Using this framework, the architecture of national multi-pillar schemes is shown in the table 6. Programs aimed to prevent poverty in old age - first-tier, redistributive schemes - are provided by the public sector and of three main types: Resource-tested; Basic; Minimum.

Resource-tested or targeted plans pay a higher benefit to poorer pensioners and reduced benefits to better-off retirees. In these plans, the value of benefits depends either on income from other sources or on both income and assets. All countries have general social safety-nets of this type, but in some cases they only cover a few older people who experienced many career interruptions. Rather than mark every country in the table, only 12 OECD countries are marked in this column. Full-career workers with low earnings ( $30 \%$ of the average) would be entitled to resource-tested benefits in these countries. Basic schemes pay either flat-rate benefits (the same amount to every retiree) or their value depends only on years of work, not

\footnotetext{
${ }^{14}$ See Mariusz Dybał, 'Istota i rodzaje systemów emerytalnych' in Leon Olszewski (ed.) Ekonomia 18 (Wydawnictwo Uniwersytetu Wrocławskiego 2010) 237.

$15<\mathrm{http}$ ://dx.doi.org/10.1787/5k9180xv25xw-enf $>$ accessed 18 November 2012.
} 
on past earnings. Additional retirement income does not change the entitlement. Some 13 OECD countries have a basic pension scheme or other provisions with a similar effect. Minimum pensions, which share many features with resource-tested plans, are found in 18 OECD countries. The value of entitlements takes account only of pension income; unlike resource-tested schemes, it is not affected by income from savings, etc. Minimum credits in earnings-related schemes, such as those in Belgium and the United Kingdom, have a similar effect: benefits for workers with very low earnings are calculated as if the worker had earned at a higher level. Only Ireland and New Zealand among OECD countries do not have a mandatory second-tier provision. ${ }^{16}$

In the other 32 countries, there are four kinds of schemes: Definedbenefit (DB); points; Defined-contribution (DC); notional accounts.

Defined-benefit (DB) plans are provided by the public sector in 18 OECD countries. Private (occupational) schemes are mandatory or quasimandatory in

three OECD countries (Iceland, the Netherlands and Switzerland). Retirement income depends on the number of years of contributions and individual earnings There are points schemes in four OECD countries: French occupational plans (operated by the public sector) and the Estonian, German and Slovak public schemes. Workers earn pension points based on their earnings each year. At retirement, the sum of pension points is multiplied by a pension-point value to convert them into a regular pension payment. Defined-contribution (DC) plans are compulsory in 11 OECD countries. In these schemes, contributions flow into an individual account. The accumulation of contributions and investment returns is usually converted into a pension-income stream at retirement. In Denmark and Sweden, there are quasi-mandatory,

occupational DC schemes in addition to smaller compulsory plans. There are notional accounts schemes in four OECD countries (Italy, Norway, Poland and Sweden). These record contributions in an individual account and apply a rate of return to the balances. The accounts are 'notional' in that the balances exist only on the books of the managing institution. At retirement, the accumulated notional capital is converted into a stream of pension payments using a formula based on life expectancy. Since this is designed to mimic DC schemes, they are often called notional definedcontribution plans (NDC). ${ }^{17}$

Table 6 Structure of retirement-income provision

\begin{tabular}{|l|c|c|c|c|c|}
\hline \multirow{2}{*}{ OECD members } & \multicolumn{3}{|c|}{ Public } & Public & $\begin{array}{c}\text { Privat } \\
\text { e }\end{array}$ \\
\cline { 2 - 6 } & $\begin{array}{c}\text { Resource- } \\
\text { tested }\end{array}$ & $\begin{array}{c}\text { Basi } \\
\text { c }\end{array}$ & $\begin{array}{c}\text { Minimu } \\
\text { m }\end{array}$ & Type & Type \\
\hline Australia & $\checkmark$ & & & & DC \\
\hline Austria & & & & DB & \\
\hline
\end{tabular}

16 'Pensions at a Glance 2011: Retirement-income Systems in OECD and G20 Countries' (OECD 2011) 107.

${ }^{17} \mathrm{http}: / / \mathrm{dx}$. doi.org/10.1787/pension_glance-2011-enx $>$ accessed 18 November 2012. 


\begin{tabular}{|c|c|c|c|c|c|}
\hline Belgium & $\checkmark$ & & $\checkmark$ & DB & \\
\hline Canada & $\checkmark$ & $\checkmark$ & & $\mathrm{DB}$ & \\
\hline Chile & $\checkmark$ & & $\checkmark$ & & $\mathrm{DC}$ \\
\hline Czech Republic & & $\checkmark$ & $\checkmark$ & DB & \\
\hline Denmark & $\checkmark$ & $\checkmark$ & & & $\mathrm{DC}$ \\
\hline Estonia & & $\checkmark$ & & Points & $\mathrm{DC}$ \\
\hline Finland & & & $\checkmark$ & DB & \\
\hline France & & & $\checkmark$ & $\begin{array}{c}\mathrm{DB}+\text { point } \\
\mathrm{s}\end{array}$ & \\
\hline Germany & $\checkmark$ & & & Points & \\
\hline Greece & & & $\checkmark$ & DB & \\
\hline Hungary & & & & DB & $\mathrm{DC}$ \\
\hline Iceland & $\checkmark$ & $\checkmark$ & & & $\mathrm{DB}$ \\
\hline Ireland & & $\checkmark$ & & & \\
\hline Israel & & $\checkmark$ & & & $\mathrm{DC}$ \\
\hline Italy & $\checkmark$ & & & NDC & \\
\hline Japan & & $\checkmark$ & & DB & \\
\hline Korea & $\checkmark$ & $\checkmark$ & & $\mathrm{DB}$ & \\
\hline Luxembourg & $\checkmark$ & $\checkmark$ & $\checkmark$ & DB & \\
\hline Mexico & & & $\checkmark$ & & $\mathrm{DC}$ \\
\hline Netherlands & & $\checkmark$ & & & $\mathrm{DB}$ \\
\hline New Zealand & & $\checkmark$ & & & \\
\hline Norway & & & $\checkmark$ & NDC & DC \\
\hline Poland & & & $\checkmark$ & NDC & $\mathrm{DC}$ \\
\hline Portugal & & & $\checkmark$ & DB & \\
\hline Slovak Republic & & & $\checkmark$ & Points & $\mathrm{DC}$ \\
\hline Slovenia & & & $\checkmark$ & DB & \\
\hline Spain & & & $\checkmark$ & DB & \\
\hline Sweden & & & $\checkmark$ & NDC & $\mathrm{DC}$ \\
\hline Switzerland & $\checkmark$ & & $\checkmark$ & DB & $\mathrm{DB}$ \\
\hline Turkey & & & $\checkmark$ & DB & \\
\hline United Kingdom & $\checkmark$ & $\checkmark$ & $\checkmark$ & $\mathrm{DB}$ & \\
\hline United States & & & & DB & \\
\hline \multicolumn{6}{|c|}{ Other major economies } \\
\hline Argentina & & $\checkmark$ & & DB & \\
\hline Brazil & & & & DB & \\
\hline China & & $\checkmark$ & & NDC/DC & \\
\hline India & & & & $\mathrm{DB}+\mathrm{DC}$ & \\
\hline Indonesia & & & & DC & \\
\hline
\end{tabular}




\begin{tabular}{|l|c|c|c|c|c|}
\hline Russian Federation & & $\checkmark$ & & NDC & DC \\
\hline Saudi Arabia & & & $\checkmark$ & DB & \\
\hline South Africa & $\checkmark$ & & & & \\
\hline
\end{tabular}

Note: In Iceland and Switzerland, the government sets contribution rates, minimum rates of return and the annuity rate at which the accumulation is converted into a pension for mandatory occupational plans. These schemes are therefore implicitly defined benefit. DB = Defined benefit; $\mathrm{DC}=$ Defined contribution; NDC $=$ Notional accounts.

Source: 'Pensions at a Glance 2011: Retirement-income Systems in OECD and G20 Countries' (OECD 2011) 107.

\section{IMPACT OF FINANCIAL, DEMOGRAPHIC, AND OTHER RISKS ON PAYG AND FUNDED PENSION SYSTEMS}

The principal advantage of a multi-pillar pension scheme lies in risk diversification. Not all of the population's retirement portfolio will be held hostage to political and demographic risk, if only because the PAYG system no longer looms so large in the country's public finances. Most or all of the same issues of regulation, capital market development and market fluctuation also exist in a multi-pillar approach and require solutions. Because it is only part of a larger system, however, the funded component can operate with fewer governmental constraints on the long-run investment options offered to contributors. More importantly, the multi-pillar approach recognizes that countries face a variety of risks over the long term and no one instrument can fully anticipate all those risks. In fact, some nonsystemic risks, such as certain catastrophes, may not be diversified at all. Table 7 summarizes how a multi-pillar approach balances long-run risks. ${ }^{18}$

Table 7. Responsiveness to Main Risks

\begin{tabular}{|c|c|c|}
\hline $\begin{array}{c}\text { Type of risk\Type of } \\
\text { scheme }\end{array}$ & Unfunded Schemes & Fully-funded Schemes \\
\hline \multicolumn{3}{|l|}{ Macroeconomic Risks } \\
\hline Negative output shocks & $\begin{array}{l}\text { lower revenue, but effects on } \\
\text { individuals can be mitigated }\end{array}$ & $\begin{array}{l}\text { possible effects on } \\
\text { financing which can be } \\
\text { mitigated }\end{array}$ \\
\hline Unemployment & $\begin{array}{l}\text { lower revenue, but effects on } \\
\text { individuals can be mitigated }\end{array}$ & $\begin{array}{l}\text { no effect on financing, but } \\
\text { concerned individual } \\
\text { receives future lower } \\
\text { benefits }\end{array}$ \\
\hline Low wage growth & $\begin{array}{l}\text { lower revenue, but effects on } \\
\text { individuals can be mitigated }\end{array}$ & $\begin{array}{l}\text { no effect on financing and } \\
\text { current } \\
\text { benefit level }\end{array}$ \\
\hline $\begin{array}{l}\text { Financial crisis } \\
\text { (depression, war, } \\
\text { hyperinflation, natural } \\
\text { disaster) }\end{array}$ & $\begin{array}{l}\text { possible lower revenue, but } \\
\text { effects on individual can be } \\
\text { mitigated }\end{array}$ & $\begin{array}{l}\text { accumulated stock reduced } \\
\text { or even } \\
\text { eliminated }\end{array}$ \\
\hline Low rates of return & $\begin{array}{l}\text { no direct effects on financing } \\
\text { and benefits }\end{array}$ & $\begin{array}{l}\text { no effects on financing but } \\
\text { lower }\end{array}$ \\
\hline
\end{tabular}

${ }^{18}$ Robert Holzmann, The World Bank approach to pension reform (The World Bank 1999) 10 . 


\begin{tabular}{|l|l|l|}
\hline Demographic Risks & \multicolumn{2}{|l|}{} \\
\hline Higher dependency ratio & deteriorating financing & $\begin{array}{l}\text { no direct effects on } \\
\text { financing and } \\
\text { benefit level }\end{array}$ \\
\hline Smaller labor force & $\begin{array}{l}\text { higher wages and future } \\
\text { benefit } \\
\text { levels }\end{array}$ & $\begin{array}{l}\text { lower returns and future } \\
\text { benefit levels }\end{array}$ \\
\hline Political Risks & \multicolumn{2}{|l|}{} \\
\hline Contract change & Easy & Difficult \\
\hline $\begin{array}{l}\text { Responsiveness to short } \\
\text { and } \\
\text { long-term budget } \\
\text { constraints }\end{array}$ & High & Low \\
\hline
\end{tabular}

Source: <http://siteresources.worldbank.org/SOCIALPROTECTION/Resources/SP-

Discussion-papers/Pensions-DP/9807.pdf > accessed 18 November 2012.

Governments have realized that the advantages of a multi-pillar pension system outweigh the disadvantages. Therefore, thirteen of the thirty-four OECD countries (figure 3) have some form of mandatory or quasi-mandatory private fully-funded pension system in place, which generally ensures high coverage of the working age population. When combining PAYG and mandatory or quasi-mandatory private pension systems, net pension replacement rates for workers on average earnings are above $60 \%$ of the worker's final salary in these countries, except in Australia, Estonia, Sweden and Mexico. In total, thirteen OECD countries have an aggregate net replacement rate below $60 \%$. Two other OECD countries, Hungary and the Slovak Republic, used to have mandatory private pension systems but have recently changed enrolment rules, with a dramatic effect on coverage, especially in Hungary. In this country, the government decided to effectively close down the mandatory private pension system at the end of 2010. Contributions to the system were suspended between 1 November 2010 and 31 December 2011, with the whole of social security contributions flowing to the Pension Insurance Fund thereafter. The vast share of pension fund assets accumulated by members was transferred back to the state. As a result, coverage of the mandatory system plunged from $45.4 \%$ of the working age population at the end of 2010 (as shown o figure 3) to 1.5\% at the end of September 2011. From 2012 on, the mandatory private pension system does not exist anymore. Former participants in the mandatory private pension system will only accrue public pension rights. ${ }^{19}$

19 ‘OECD Pensions Outlook 2012’ (OECD 2012) 106. 
Figure 3. Net pension replacement rates from PAYG and mandatory private pension systems for average earners

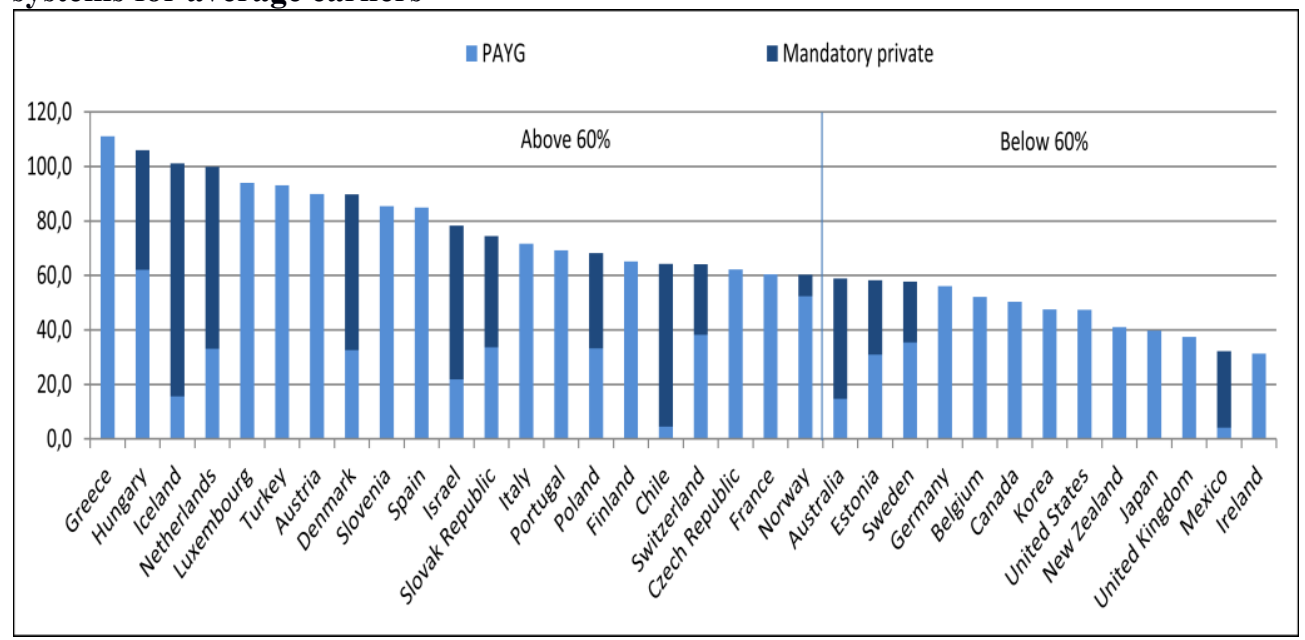

Source: 'OECD Pensions Outlook 2012' (OECD 2012) 106.

As a result of reforms, privately managed, funded pension plans are an increasingly important part of retirement income systems. As shown in Figure 4, private pensions will account for over $50 \%$ of total pension benefits for workers that start their careers today in countries such as Australia, Chile, Mexico, Poland, Slovak Republic and the United Kingdom. In these countries, private pensions for new entrants to the labour force are predominantly provided in the form of defined contribution arrangements, where members bear all investment risk during the accumulation stage. As a result, pension benefits are likely to exhibit a great degree of variability both within and across generations, even for workers with similar wage, contribution and longevity profiles. ${ }^{20}$

\footnotetext{
20 See P Antolín, 'Private Pensions and the Financial Crisis: How to Ensure Adequate Retirement Income from DC Pension Plans' (OECD 2009) $<$ www.oecd.org/dataoecd/37/14/44628862.pdf> accessed 18 November 2012.
} 
Figure 4. The role of private pensions in the overall retirement income package by type of provision

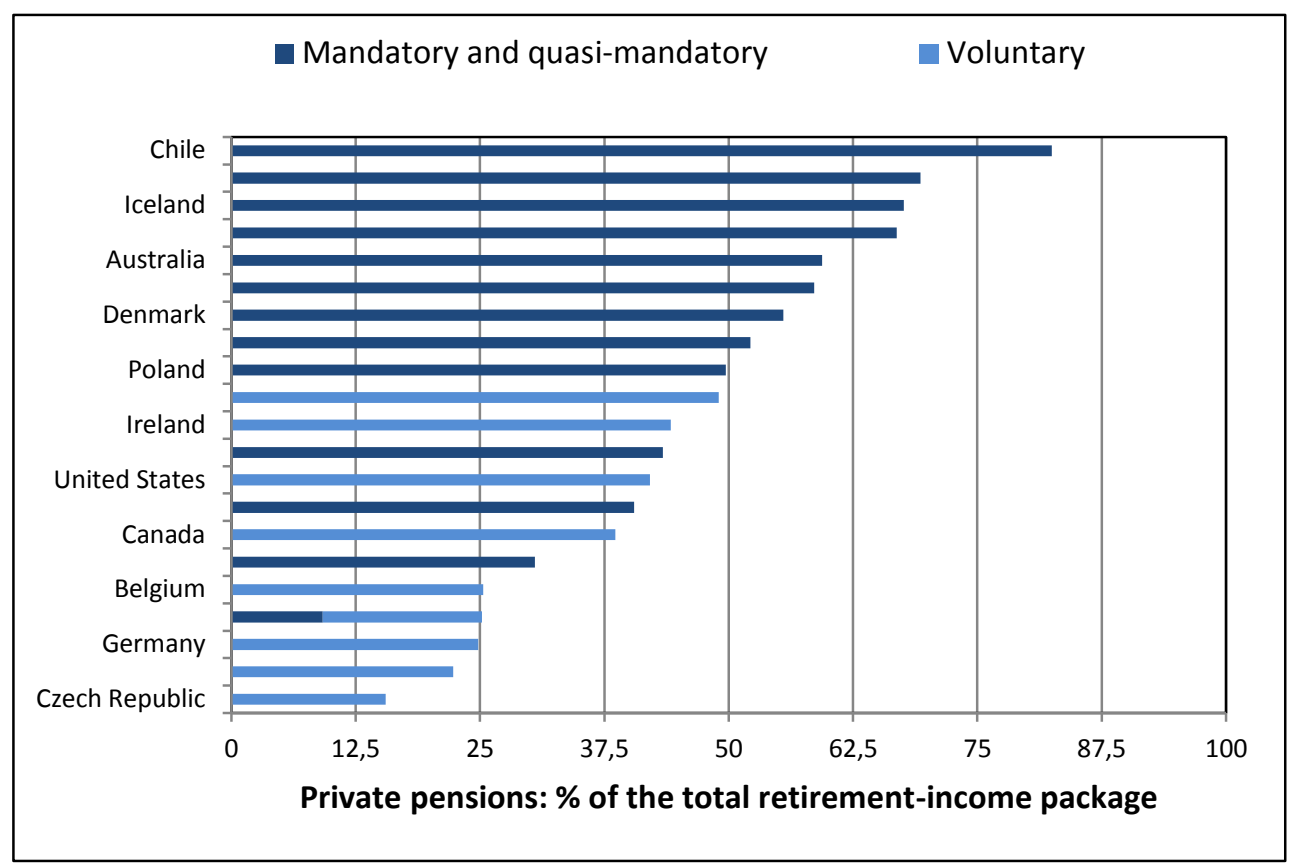

Notes: Countries with mandatory or quasi-mandatory private pension systems may also have a voluntary part which is not shown here.

The calculations are based on national pension rules and parameters applying in 2008.

Source: <http://dx.doi.org/10.1787/888932598702> accessed 18 November 2012.

\section{Conclusions}

In order to adapt pension systems to demographic trends, many countries are reducing pay-as-you-go public pension levels and altering retirement ages. In this context, funded private pensions as a part of a multipillar system could play an important role in avoiding adequacy gaps. Therefore, as this article shows, the coverage of funded pensions is highly uneven across countries and between individuals, especially in voluntary systems. Some countries have made funded pensions compulsory (e.g. Australia, Chile, Poland) or quasi-mandatory (e.g. the Netherlands) to ensure that most workers are covered and therefore have access to a sufficiently high complementary pension. However, in other countries with relatively low PAYG public pension benefits, funded private provision remains voluntary. The low level of funded pensions' coverage in those countries should be a major policy concern.

To conclude, countries all over the world are reforming their pension systems. Most are reforming to decrease the fiscal costs of their existing pension systems. A few relatively young countries are establishing new systems or are increasing the generosity of their current systems, although perhaps not always taking into account the future fiscal costs entailed in the increased generosity. Nevertheless, the majority of the pension reforms are tinkering with an existing pay-as-you-go defined benefit system, rather than 
reform of the overall system of pension provision. However, while these minor reforms alleviate some of the fiscal burden, fiscal problems reappear in the long term. The only way to effectively solve the pension system issue on a permanent basis is to move toward the fully-funded defined contribution reforms currently underway in Latin America, Australia, Central and Eastern Europe and under consideration in a variety of other countries. 